\title{
§ II The Nineveh Manuscripts of Chapter Two (IGI 2)
}

TITLE

\author{
If A Man's Eyes Are Full of Murdinnu-Brambles \\ šumma(DIŠ) amēlu(NA) ìnāšu(IGI.MIN-šú) mur-din-ni malâ(DIRI) \\ = Assur Medical Catalogue 1. 8.
}

\section{Sigla notations:}

$\mathbf{N}=$ Nineveh, Neo-Assyrian. A, B, C, ... designate the different manuscripts.

Translation in italics are tentative reconstructions based on parallels.

Base Manuscript: ND (BAM 515), collated.

Museum number: $\quad$ British Museum, K $1845+2440+\mathrm{K} 2444+2500+2501+2504+2508$ $+2762+3662+4116+6425+6652+6974+7933+8349+8832+$ $9247+10495+10790+10892+11803+15454+15765+15769+\mathrm{Sm}$ 1308.

Origin and date: Nineveh, $7^{\text {th }}$ century BC.

Type of tablet: Two-column, portrait-oriented tablet. The two vertical dividing rulings were made by a twisted thread. There are no round holes visible in the preserved parts.

Measurements: $\quad$ ca. $31 \times 18 \times 3,3$ (upper edge) $-3,6$ (towards the middle) $\mathrm{cm}$.

Copy: $\quad$ BAM 515.

Photo/CDLI nr.: $\quad$ Plates 19-26/P394104.

Literature: $\quad$ Köcher 1980b: xif., BAM 515; Fincke 2000: 331. Scurlock and Andersen 2005: 793; Fincke 2009; Scurlock 2014: 756; Attia 2015.

\section{§ II.1 Related Manuscripts containing IGI 1 and 3 from Nineveh}

The texts included represent parallels and partial parallels from the other tablets of the IGI treatise.

Manuscript: $\quad$ NA (BAM 510), see § I.1, parallels: 1, 117ff.', 215’.

Manuscript: $\quad$ NB (BAM 513), see $\$$ I.1, parallels: 117ff.'.

Manuscript: $\quad$ NC (BAM 514), see § I.1, parallels: 117ff.', 215’.

Manuscript: $\quad$ NE (BAM 516), see § III.1, parallels: 215’. 


\section{§ II.2 Related other Manuscripts from Nineveh}

The texts included represent parallels and partial parallels which are considered important for the compilation of the IGI-treatise. They come from other tablets and fragments from Nineveh containing prescriptions for sick eyes or from the UGU-treatise.

Manuscript: $\quad$ NI (BAM 480), see $\$$ V.1, parallels: 62', 71', 147’, 157’.

Manuscript: $\quad$ NK (BAM 518), see § IV.2, parallels: 10.

\section{§ II.3 Related Manuscripts from Different Cities}

The texts included here represent parallels and partial parallels which are considered important for the compilation of the IGI-treatise. These are manuscripts coming from other periods and from cities other than Nineveh.

\section{Sigla notations:}

A = Assur, Late Assyrian. A, B, C, ... designate the different manuscripts.

$\mathbf{b}=$ Babylon, Late Babylonian. A, B, C, ... designate the different manuscripts.

Bo = Boğazköy, Hattuša, Hittite period. A, B, C, ... designate the different manuscripts.

$\mathbf{K}=$ Kalhu, Late Assyrian. A, B, C, ... designate the different manuscripts.

$\mathbf{s}=$ Sippar, Late Babylonian. A, B, C, ... designate the different manuscripts.

$\mathbf{u}=$ Uruk, Late Babylonian. $A, B, C, \ldots$ designate the different manuscripts.

$\mathbf{x}=$ unknown provenance, Late Babylonian. A, B, C, ... designate the different manuscripts.

Initial capital letters designate tablets in Assyrian script or northern scripts, and small letters tablets in Babylonian script.

Parenthesis [0] on a siglum designate a parallel text and not a duplicate.

\section{Hattuša}

Manuscript: $\quad$ BoA (KUB 4/50), photo collated, parallels: 145’.

Museum number: Istanbul, Bo 3928.

Origin and date: Boğazköy, Hattuša. Hittite period.

Type of tablet: $\quad$ Too fragmentary to judge.

Copy: KUB 4/50.

Photo: Mainzer Photoarchiv, http://www.hethport.uni-wuerzburg.de /HPM/index.html, CTH 809.

Literature: $\quad$ Fincke 2010; Schwemer 2013: 156. 


\section{Assyrian}

Manuscript:

Manuscript:

Manuscript:

Manuscript:

Museum number:

Origin and date:

Type of tablet:

Measurements:

Copy:

CDLI nr.:

Literature:

Manuscript:

Museum number:

Origin and date:

Type of tablet:

Measurements:

Copy:

CDLI nr.:

Literature:

Manuscript:

Museum number:

Origin and date:

Type of tablet:

Measurements:

Copy:

CDLI nr.:

Literature:
AA (BAM 20), see $§$ I.4, parallels: 10f., 117ff.'.

AB (BAM 159), see § I.4, parallels: 58', 117ff.'.

AD (BAM 22), see § I.4, parallels: 22ff., 65f.', 98f.'.

AF (BAM 23), collated, parallels: 71', 121', 137ff.'.

Vorderasiatisches Museum, Berlin, VAT $13782+13904$.

Assur, Late Assyrian.

One-column, landscape-oriented tablet.

$13,3 \times 6,7 \times 2,2 \mathrm{~cm}$.

BAM 23.

P285125.

Köcher 1963: xv; Fincke 2000: 329; Scurlock and Andersen 2005: 784; Attia 2015: 47.

AG (BAM 15), collated, parallels: 207f.'.

Vorderasiatisches Museum, Berlin, VAT 13892.

Assur, Late Assyrian.

Too fragmentary to judge. It was not fired, but pressure exercised over the tablet while in a wet state, thus it turned convex. It shows large script.

ca. 7,4 ×5,4×2,4 cm.

BAM 15.

P285118.

Köcher 1963: xv; Fincke 2000: 329; Scurlock and Andersen 2005: 784; Attia 2015: 52.

KA (CTN 4/123), collated, parallels: 53'.

British Museum, London, ND 04405/16

Kalhu, Late Assyrian.

Too fragmentary for certainty.

ca. $5,1 \times 6,7 \times 2,5 \mathrm{~cm}$

CTN 4/123.

P363537.

Wiseman and Black 1996: no. 123; Worthington 2005: 7ff.; Scurlock 2014: 758. 


\section{Babylonian}

Manuscript: $\quad$ bB (BAM 382), collated, parallels: $25 f$.

Museum number: $\quad$ Vorderasiatisches Museum, Berlin, VAT 17406.

Origin and date: Babylon, Late Babylonian.

Type of tablet: One-column, landscape-oriented tablet.

Measurements: $\quad 7 \times 4,2 \times 2,1 \mathrm{~cm}$.

Copy: BAM 382.

CDLI nr.: $\quad$ P285453.

Literature: $\quad$ Köcher 1971: xxvii; Fincke 2000: 329; Scurlock and Andersen 2005: 790; Attia 2015: 39.

Manuscript: $\quad$ SA (IRAQ 65), see § I.4, parallels: 10, 65f.', 98f.'.

Manuscript: $\quad$ uA (SpTU 50), see § I.4, parallels: 58', 215’.

Manuscript: $\quad$ uB (NBC 4211), photo collated, parallels: 25.

Museum number: Yale Babylonian Collection, New Haven, NBC 4211.

Origin and date: Uruk, Late Babylonian.

Type of tablet: One-column, portrait oriented tablet.

Measurements: ca. $13,4 \times 9,6 \times 2,6 \mathrm{~cm}$.

CDLI nr.: $\quad$ P290281.

Literature: $\quad$ Beaulieu 1994: 25.

Manuscript: $\quad$ XA (CM 37), see § I.4, parallels: 23f., 58’, 215’.

\section{$\S$ II.4 Synopsis of the Prescriptions of Chapter Two (IGI 2)}

1ff. Prescriptions and medical applications for eyes full of murdinnu-brambles (a disease): bandage for three days with a plant and roasted grain in beer, three times re-bandaging the eyes and smearing the eyes with gazelle knuckle-fat. Pounding the substances into a lead salve, spattering a dried plant over the eyes, and re-bandaging. Again, three times a day re-bandaging, spattering dried plants over the head, keeping the bandage for three days. On the fourth day releasing the bandage, shaving the head, daubing the eyes: prognosis for recovery.

8f. No diagnosis in the beginning, but this time at the end; this prescription for eyes suffering from 'sun-heat' and murdinnu-brambles: eight drugs including a bat guano, plants, minerals, and river silt, applied as eye drops.

10 No diagnosis (but presumably the same as the previous one): a plant, a mineral, a saline solution applied as eye drops. 
11 No diagnosis (but presumably the same as the previous one): a plant, a mineral, a saline solution applied as eye drops.

12ff. Ritual/medical application for giddagiddû-fibers, ritual/medical application acts at the door of man's house.

16 Prescription for 'spoiled' blood; plant ingredients.

17f. Prescription for blurred vision due to abnormal hair growth in the eyes; mixture of plants, animal fats, honey and ghee, applied by daubing.

19ff. Prescription for eyes full of loose tissue; pounded plants in honey applied by daubing; alternative mineral treatment in ghee, applied by daubing?.

22ff. Prescription for eyes full of loose tissue: making a 'clod' from plants, fat, and bat guano mixed in cedar 'blood' (i.e. resin) and oil; mixture is applied by daubing.

25f. Prescription for eyes full of tissue and blood: salve with plants, bat guano; applied by daubing.

27ff. Prescription and medical application for eyes full of qūqānu-'worms': rit$\mathrm{ual} /$ medical application acts of burying materia medica and magica under a threshold.

50f. $\quad$ Prescription for ...: daubing the eys with bone marrow and; salve from bone marrow and, pounded in honey, ghee, plant oil and copper patina; applied by daubing.

52f.' No diagnosis (but presumably as the previous one): pounded flour, grains poured directly into the eyes.

53' Fragmentary prescription: salve from animal fats and wax, pounded in bone marrow; applied by daubing.

54f.' Prescription for foreign objects in the eye, and dimmed eyes with chronic suffering and cloudy eyes; recipe demaged.

56' Prescription for inflamed eyes: bandage of crushed and sifted plants with grain flour in beer.

57 No diagnosis (but presumably as the previous one): eye drops made from a plant, a mineral, and a saline solution.

58f.' Prescription and medical application for dim eyes: ritual/medical application acts of burying materia medica and magica under a threshold.

60' Fragmentary prescription: daubing the eyes.

61f.' Prescription for darkened eyes: salves from oils, copper patina, and fungusridden potsherd, mixed in mountain honey; applied by daubing?

63f.' Prescription for 'pressed' eyes: sap of a fresh plant applied over the face/eye, salve with copper patina and sesame oil; applied by daubing.

65f.' Prescription for the same case: grated plant into milk, baked, and pounded (with) plants and a mineral; applied by daubing.

67' Prescription for the same case: parched crumbled bread applied on the eyes as eye drops.

68 Prescription for the same case: [bandage] with plant based powder. 
69 Prescription for the same case: salve of plants in milk; applied by daubing.

70' Prescription for the same case: salve of mineral in ghee; applied by daubing; salve of mineral in bone marrow; applied by daubing.

71' Prescription for the same case: pickling of a turtle gall bladder in salt, to be dried out and pounded in oil, and a copper patina; applied by daubing.

72' Prescription for the same case: pounded substance using a bronze knife in ghee; applied daubing.

73' Prescription for the same case: plants in sesame oil, a daubing applied with the finger.

74' Two prescription for the same case: salve from lizard's head and oil; applied by daubing; salve with pounded wall lizard and charcoal; applied by daubing.

75' No diagnosis (but presumably as the previous one): salve from a sheep's ribcage; applied by daubing.

76' Prescription for closed eyes: dripping into the eyes of substance(s) mixed in ghee.

77f.' No diagnosis (but presumably as the previous one): wild cow brain mixed in sesame oil and male pigeon brain, prepared over three days [on a cosmetic palette]; applied regularly as a salve into the eyes.

79ff.' No diagnosis (but presumably as the previous one): raven egg smeared on a bronze knife, ...; applied by daubing

82' Fragmentary prescription: daubing.

83' Fragmentary prescription: daubing.

84' Fragmentary prescription: salve of substance(s) in sesame oil, pounded in red paste; applied by daubing

85' Fragmentary prescription: salve of substance(s) in sesame oil, pounded with frit and cedar oil; applied by daubing

86' Fragmentary prescription: salve of substance(s) in oil in a copper kettle; applied by daubing

87 Fragmentary prescription: salve of plants; applied by daubing

88, Fragmentary prescription: salve of substance(s) in oil; applied by daubing

89' Fragmentary prescription: medication dripped into the eyes.

90f.' Fragmentary medical application prescription: medical application acts with a lamp and its smoke, rinsing the eyes.

92f.' Fragmentary prescription: salve with bat guano, pounded with a lead spoon in oil and copper patina; applied by daubing.

94f.' Fragmentary prescription: preparation of a salve with patina in a copper kettle, daubing the eyes for seven days.

96f.' Fragmentary prescription: salve from ingredients in fat; applied by daubing.

98f.' Prescription for kiṣ̂tu 'skinned' and closed eye lids: salve of a skinned plant in püru-oil; applied by daubing; salve of old copper in ghee; applied by repeated daubing; prognosis for recovery. 
100f.' Fragmentary prescription: salve of plants pounded in patina; applied by daubing.

102' Fragmentary prescription: salve of parched and crushed ingredients, pounded in patina; applied by daubing.

103' Fragmentary medical application prescription: burying of substances under a threshold for seven days, pounded in patina into a salve; applied by daubing.

104' Fragmentary prescription: ingredients pounded in patina into a salve; applied by daubing.

105ff.' Fragmentary medical application prescription: pricking (birds') eyes with a needle, producing a salve; applied by daubing.

108ff.' Fragmentary prescription for kurāru-pustle on the eyelids: bandage from plants, seeds, ewe hoof, goat kidney kept fifteen days; daubing the eyes for three more days with a plant ingredient.

115' Prescription for eyes full of yellowness (jaundice): blowing pounded pomegranate peel via a reed-straw into the eyes.

116' Prescription for eyes full of yellowness (jaundice): two salves of pomegranate peel, first in oil, then in saline solution; applied by daubing.

117ff.' Prescription for sick closed eyes, with fever and filmy vision: shaving the head, cooling it with dough, salve of plants and ghee; applied by daubing and rinsing the eyes.

120' No diagnosis (but presumably as the previous one): salve of plant in mountain honey and ghee; applied by daubing.

121ff.' Prescription for membrane-covered eyes with tears and dark spots: salve from plants, bat guano mixed in cedar oil; applied by daubing: prognosis for recovery.

124f.' Prescription for membrane-covered eyes with opaque vision and white spot on the pupil: salve of plants mixed in cedar oil; applied by daubing.

126f.' Fragmentary prescription for opaque vision: salve; applied by daubing.

128ff. Fragmentary prescriptions: blowing medication into the eyes, fumigation, and daubing: prognosis for recovery.

137f. Fragmentary prescription: application with different resins for eight months.

139' Prescription for eyes full of film: salve of pounded potsherd, white plant and ghee; applied by daubing.

140' Prescription for the same case: medication containing bat guano, and spattered into the eyes.

141' Fragmentary prescription for the same case: two salves from bat guano in ghee, and pounded potsherd; applied by daubing.

142f.' No diagnosis (but presumably as the previous one): salve of a plant in ghee, applied three times, another ghee salve, daubing.

144f.' Fragmentary prescription: salve of a bat guano in ghee, daubing three times a month; bandage of plant leaf in vinegar; squeezing plant sap into the eyes. 
146' Fragmentary prescription: salve of grain powder and saline solution; applied by daubing.

147' Fragmentary prescription: salve of copper patina in fat of gazelle's thigh; applied by daubing.

148 Fragmentary prescription: salve, and dripping honey and fat into the eyes.

149'-193' Fragmentary and unclear.

194' No diagnosis (but presumably as the previous one): salve of (pounded) potsherd, salt cedar oil, daubing.

195' No diagnosis (but presumably as the previous one): salve of a plant and a saline solution in honey; applied by daubing.

196' Fragmentary and unclear.

197f.' Fragmentary and unclear.

199' Prescription for eyes full of film, fragmentary and unclear.

200ff.' Surgical prescription for left and right eyes full of film: treatment with a scalpel, fragmentary and unclear.

204' Prescription for sick eyes with milk, fragmentary and unclear.

205' No diagnosis (but presumably as the previous one): eagle's brain in mothers' milk, fragmentary and unclear.

206' No diagnosis (but presumably as the previous one): plant seeds and powder, rest fragmentary.

207f.' Two prescriptions for eyes full of film: a salve applied by daubing.

209ff.' Fragmentary prescriptions, eyes full of film.

215ff.' Catchline of tablet three, designation of tablet two, and preserved Ashurbanipal colophon. 